\title{
Increased cropping intensity improves crop residue inputs to the soil and
}

\section{aggregate-associated soil organic carbon stocks}

\author{
Leonardo E. Novelli ${ }^{\text {a,* }}$, Octavio P. Caviglia ${ }^{\text {a,b,c }}$, Gervasio Piñeiro ${ }^{\text {d }}$ \\ ${ }^{a}$ Facultad de Ciencias Agropecuarias - Universidad Nacional de Entre Ríos. Ruta 11.
} Km 10,5 (3100) Paraná. Argentina.

b INTA EEA Paraná. Ruta 11. Km 12,5 (3100) Paraná. Argentina.

${ }^{\mathrm{c}}$ CONICET

${ }^{\mathrm{d}}$ IFEVA/Facultad de Agronomía - Universidad de Buenos Aires/CONICET. Av. San Martín 4453, Bs. As. Argentina.

\begin{abstract}
Many South American agroecosystems are based mainly on soybean [Glycine max (L.)

Merr.] as a sole crop in the year, which has increased concerns regarding soil conservation and ecosystems sustainability. The increase in cropping intensity (CI) has been suggested as a strategy to improve crop residue inputs, which in turn, may increase soil aggregation and soil organic C (SOC) storage, while maintaining or even increasing total sequence yields. Our objective was to evaluate the relationships between CI and crop residue input with SOC storage and soil aggregation in two contrasting northeastern Argentinean Pampas soils under no-till. Two parallel experiments were established in a Mollisol and a Vertisol evaluating six cropping sequences, starting from soybean monoculture and increasing the number of crops per year and crop diversity. Crop residue inputs to the soil (aboveground biomass, belowground biomass and total
\end{abstract}

\footnotetext{
${ }^{*}$ Corresponding author at: Facultad de Ciencias Agropecuarias - UNER, Ruta 11, km 10.5 (3101), Oro Verde, Paraná, Argentina. Tel.: +54 3434975075.

E-mail address: lnovelli@fca.uner.edu.ar (L.E. Novelli).
} 
biomass), grain yield, the amount of macroaggregates (MA), SOC stored inside macroagregates $\left(\mathrm{SOC}_{\mathrm{MA}}\right)$ and total SOC stocks were measured in both soils two years after the beginning of cropping sequences, at three soil depths. Soil organic C stocks, MA and $\mathrm{SOC}_{\mathrm{MA}}$ were all positively related with $\mathrm{CI}$ in both soils at $0-5 \mathrm{~cm}$ depth. All soil variables were lowest in simple rotations (soybean monoculture) and increased with more complex rotations (double cropping with cereals and legumes), although differences were significant $(\mathrm{P}<0.05)$ only in the top soil $(0-5 \mathrm{~cm}$ depth). Grain yields and crop residues followed a similar pattern being higher in rotations that included maize (with yields expressed as grain mass or as glucose equivalent mass) and lower in soybean monocultures. The highest protein yields were obtained in sequences with wheat and soybean double cropping. Increases in CI under no-till seem to be a useful strategy to improved residue inputs, soil aggregates and SOC stocks. Our results provide valuable evidence for stakeholders and policy-makers to improve SOC sequestration and soil health in agroecosystems of humid temperate croplands.

Keywords: Mollisol, Vertisol, Cropping rotations, Soil aggregations, SOC stocks, croplands

\section{Introduction}

Soil organic carbon (SOC) losses have been associated with intensive tillage, crop monocultures and long fallow periods in the crop sequences (Franzluebbers et al., 1994; Studdert and Echeverría, 2000, Sherrod et al., 2003; Novelli et al., 2011). The lack of crop rotations, even under no-till, could lead to both SOC and productivity losses if $\mathrm{C}$ inputs to the soil from addition of crop residues are lower than $\mathrm{C}$ outputs by decomposition or erosion (Pittelkow et al., 2015). These losses may be exacerbated if 
agriculture is conducted on lands with low productivity and high proneness to soil degradation, a frequent situation in many agroecosystems of South America (Calviño and Monzón, 2009; Paruelo et al., 2006; Nosetto et al., 2012; Wingeyer et al., 2015). Increased concerns regarding soil conservation and ecosystems sustainability favored a rapid adoption of no-till in southern Brazil and Argentina. The success of notill in this region became an important reference for its widespread adoption throughout South America. Currently, NT is being used on 70\%-90\% of the grain crop area in Paraguay, Brazil, Argentina, Bolivia, and Uruguay (Wingeyer et al., 2015). However, despite of the extended use of no-till in this region, there is a lack of defined rotation. In fact, soybean is currently cultivated under no-till as a sole crop in the year in $67 \%$ of South American croplands (Wingeyer et al., 2015).

Compared with cereals, soybean returns less crop residue with a low $\mathrm{C}: \mathrm{N}$ ratios to the soil (Wright and Hons, 2004). It has been shown that fast decomposition of soybean residues increases susceptibility to erosion under fallow periods and the rate of SOC loses, particularly in soils with a high soybean cropping frequency (Novelli et al., 2011).

Increasing cropping intensity $(\mathrm{CI})$ is a reliable alternative to restore diversity to currently simplified crop sequences and to potentially reduce agricultural pressure on natural lands (Doré et al., 2011). Cropping intensity may be defined as the length of the period with actively growing (green) crops in a sequence, on a yearly-basis (Boserup, 1965, Caviglia y Andrade, 2010). High CI maintains continuous crop roots and soil biota activity (Acosta-Martínez et al., 2007), enhances the amount and frequency of residue inputs (Franzluebbers et al., 1994; Caviglia et al., 2011), and reduces raindrop impacts on the soil by providing continuous protection via crop canopies or crop residues (Wischmeier and Smith, 1978; Shaver et al., 2003). 
In several environments, increased CI has been useful to increase SOC storage (Wood et al., 1990, 1991; Franzluebbers et al., 1994; Peterson et al., 1998; Bowman et al., 1999; Sherrod et al., 2003; Álvaro-Fuentes et al., 2009; Luo et al., 2010) and improve other soil physical properties such as water infiltration and retention, bulk density, and the formation and stabilization of soil aggregates (Shaver et al., 2003; Álvaro-Fuentes et al., 2008). Stable soil aggregates are critical for sustainable agroecosystems, due to their influence on several soil biological and physical processes such as root growth and water and air movement that, in turn, directly affect crop productivity (Kasper et al., 2009). Furthermore, soil aggregation is an important process for SOC preservation and storage, because binding of soil particles and organic matter imposes a physical barrier between decomposers and SOC (Chung et al., 2009).

To date, the effects of decreasing the time in fallow by increasing CI on soil productivity, soil aggregation and SOC storage have been explored more intensively in semiarid regions than in humid temperate regions (Farahani et al., 1998; Bowman et al., 1999; Sherrod et al., 2003, Shaver et al., 2003; Blanco-Canqui et al., 2010; Mikha et al., 2010). In humid temperate regions with a long growing season, as the northeastern Argentinean Pampas, fallow periods may be sensibly shortened by including two crops in a year (double cropping), adding a winter crop or a cover crop to traditional summer crops. These intensification alternatives may increase grain yields and residue inputs per unit area and year (Caviglia et al., 2011, 2013; Monzón et al., 2014). However, knowledge on how the relationship between crop residue input and SOC storage are affected by $\mathrm{CI}$ in this region is still lacking, particularly under different soil types. In fact, the typical northeastern Argentinean Pampas soils (Mollisols and Vertisols), have shown different responses between SOC and aggregate stabilization (Novelli et al., 2013), suggesting that CI effects may be different in these two soils type. 
Our objective was to evaluate the relationships between CI and crop residue input with SOC storage and soil aggregation in two contrasting northeastern Argentinean Pampas soils under no-till. We hypothesized that, increased CI: i) improves residue input, which would in turn increase soil aggregation and SOC stocks, maintaining or even increasing total crop yields and; ii) affects SOC storage in a Mollisol more than in a Vertisol due to the differences in the amount of crop residues returned to the soil and the mechanisms involved in SOC protection and stabilization.

\section{Materials and methods}

\subsection{Study sites and cropping sequences}

Two identical field experiments under no-till, spaced $2 \mathrm{~km}$ apart, were conducted from May 2008 to June 2010 in sites with contrasting soils (Mollisol and Vertisol) at the Paraná Experimental Station of National Agricultural Technology Institute (INTA) $\left(31^{\circ} 50.9^{\prime} \mathrm{S}, 60^{\circ} 32.3^{\prime} \mathrm{W}\right)$, Entre Ríos province (northeastern Pampas of Argentina). The Mollisol was classified as a fine, mixed, thermic Aquic Argiudoll (Soil Survey Staff, 2010) of the Tezanos Pinto Series, with $45 \mathrm{~g}$ sand, $679 \mathrm{~g}$ silt and $276 \mathrm{~g}$ clay $\mathrm{kg}^{-1}$ in the Ap horizon (0-17 cm depth) (Plan Mapa de Suelos, 1998). The Vertisol was classified as fine, smectitic, thermic Typic Hapluderts (Soil Survey Staff, 2010) of the Febre Series, with $56 \mathrm{~g}$ sand, $542 \mathrm{~g}$ silt and $402 \mathrm{~g}$ clay kg${ }^{-1}$ in the Ap horizon (0-18 cm depth) (Plan Mapa de Suelos, 1998). Both experimental sites were cropped with maize before the beginning of the experiments and had been under no-till management for at least $15 \mathrm{yr}$ in a fixed rotation wheat/soybean double crop-maize (three crops in two years). Initial soil analysis $(0-20 \mathrm{~cm}$ depth) at the beginning of the experiments (May 2008) were for the Mollisol $\mathrm{pH}=6.2, \mathrm{P}-\mathrm{bray}=20.8 \mathrm{mg} \mathrm{kg}^{-1}$, total $\mathrm{SOC}=2.1 \%$ and total $\mathrm{N}=0.18 \%$ and for the Vertisol $\mathrm{pH}=7.7, \mathrm{P}-\mathrm{bray}=5.8 \mathrm{mg} \mathrm{kg}^{-1}$, total $\mathrm{SOC}=2.7 \%$ and 
total $\mathrm{N}=0.19 \%$. Details on monthly rainfall, mean air temperature and potential evapotranspiration (Penman-Monteith method, Allen et al., 2006), are provided in Table 1.

Six two-year cropping sequences which varied in CI were evaluated (Fig. 1). They were: i) soybean monoculture (S-S), ii) soybean with a previous wheat cover crop (CC) $(\mathrm{CC} / \mathrm{S}-\mathrm{CC} / \mathrm{S})$, iii) wheat/soybean sequential double crop, i.e. two crops in the same year (W/S-W/S), iv) two sole crop rotation with soybean followed by maize (S$\mathrm{M})$, v) soybean with maize rotation including a previous wheat CC before soybean $(\mathrm{CC} / \mathrm{S}-\mathrm{M})$ and vi) three-crop wheat/soybean-maize (W/S-M) rotation. Treatments were established in a randomized complete block design with four replicates. Plots were $5 \mathrm{~m}$ wide and $30 \mathrm{~m}$ long. Both experimental sites had similar slopes (5.2\%) and terraces for erosion control. Our work is focused on the initial effects (two year after the beginning of the experiment) of CI on total sequence yield, crop residue input, SOC stocks and soil aggregation. This is a critical period that strongly influences farmer's adoption of management strategies, such as crop rotation or the use of cover crops. However, the adoption of a new management strategy for the farmers is often more based on crop yield than on soil variables. Therefore, the improvement in soil health indices by the adoption of sequences with a higher CI should be reached maintaining or even increasing total crop yields.

The proportion of the year with actively growing (green) crops in the sequence, i.e. the ratio between the number of weeks with green-crop cover and the total length of the crop sequence, was used to calculate CI (Franzluebbers et al., 1994; Novelli et al., 2013). Considering a total of length of the crop sequence of 104 weeks in two years, we consider a period actively growing crops of 45 weeks $(\mathrm{CI}=0.43)$ for the sequence $\mathrm{S}-\mathrm{S}$, 46 weeks $(\mathrm{CI}=0.44)$ for the sequence $\mathrm{S}-\mathrm{M}, 63$ weeks $(\mathrm{CI}=0.61)$ for the sequence CC/S- 
M, 69 weeks $(\mathrm{CI}=0.66)$ for the sequence W/S-M, 80 weeks $(\mathrm{CI}=0.76)$ for the sequence $\mathrm{CC} / \mathrm{S}-\mathrm{CC} / \mathrm{S}$ and 93 weeks $(\mathrm{CI}=0.89)$ for the sequence W/S-W/S. This calculation of CI allows a better estimation of the occupation period in sequences that include cover crops, in contrast with the usual calculation based on the number of grain crops per year (e.g. Wood et al., 1990; Farahani et al., 1998; Peterson et al., 1998).

\subsection{Crop management}

Crop management was similar in both experiments (Mollisol and Vertisol). Planting date for wheat (BioINTA 3004, spring wheat cultivar), both for grain or cover crop, was May 12, 2008 and June 9, 2009, using a seeding rate of 320 seeds $\mathrm{m}^{-2}$ in rows spaced $0.21 \mathrm{~m}$ apart. Soybean (N6411, maturity group VI, determinate growth habit) was planted in November 12, 2008 as a single crop (treatments S-S and S-M) or after killing the cover crop (treatments CC/S-CC/S and CC/S-M) and in December 5, 2008, after wheat harvest in sequences that included sequential double crop (treatments W/S$\mathrm{W} / \mathrm{S}$ and $\mathrm{W} / \mathrm{S}-\mathrm{M})$, using a seeding rate of 38 seeds $\mathrm{m}^{-2}$ in rows spaced $0.53 \mathrm{~m}$ apart. Maize (DK 747 RR, single-cross hybrid) was planted in October 21, 2009, with a seeding rate of 7.7 seeds $\mathrm{m}^{-2}$ in rows spaced $0.53 \mathrm{~m}$ apart. Phosphorus fertilizer (diammonium phosphate, $180 \mathrm{~g} \mathrm{~N} \mathrm{~kg}^{-1}, 20 \mathrm{~g} \mathrm{P} \mathrm{kg}^{-1}$ ) was broadcast annually, over all treatments, immediately after wheat sowing at a rate of $120 \mathrm{~kg} \mathrm{ha}^{-1}$. Nitrogen fertilizer (urea, $460 \mathrm{~g} \mathrm{~N} \mathrm{~kg}^{-1}$ ) in wheat and maize was annually broadcasted, immediately after sowing at a rate of $250 \mathrm{~kg} \mathrm{~N} \mathrm{ha}^{-1}$ to avoid $\mathrm{N}$ limitations. Weed and insect control were performed as needed according to best management practices with specific herbicides and insecticides recommended for each crop (CASAFE, 2005). 


\subsection{Crop sampling scheme}

Aboveground biomass samples were taken from $0.44 \mathrm{~m}^{2}$ in wheat plots, $0.68 \mathrm{~m}^{2}$ in maize plots and $0.74 \mathrm{~m}^{2}$ in soybean plots. In all crops, aboveground biomass did not included grains, and was obtained from samples one or two sampling dates around crop physiological maturity to allow estimating the real crop residue inputs to the soil. In wheat crops samples were taken at Z91 growth stage scale (Zadocks et al., 1974) and at R6 growth stage for maize (Ritchie and Hanway, 1982) In wheat as a cover crop plots, biomass samples were taken in period Z40 (Zadocks et al., 1974) in the first week of October, which is within the recommended period for suppressing cover crops in the region (Caviglia and Andrade, 2010). Immediately after biomass sampling, wheat cover crops were suppressed with specific herbicides (CASAFE, 2005). In soybean plots, aboveground biomass was determined from two sampling dates, in order to account for the anticipate leaf abscission. The first sample was taken at R5.5 growth stage (Fehr and Caviness, 1977), when the maximum leaf area is reached (Herman, 1985) to account for the leaf mass. The second sample was taken at R8 growth stage (Fehr and Caviness, 1977), after total leaf abscission. Aboveground biomass for soybean was obtained as the sum of leaf mass (lamina + petiole) at R5.5 growth stage and aboveground biomass at R8 growth stage without grain (stems and pod shells). We used this sampling scheme because of its simplicity, although we realize that sampling at R5.5 growth stage could overestimate aboveground biomass due to premature leaf senescence if water stress occurred between R5.5 and R8 (Caviglia et al., 2011), since a portion of dry matter may be remobilized from the leaf to the growing seeds under these environmental conditions.

Belowground biomass was estimated considering belowground to aboveground biomass ratios (including grains) of $12.7 \%$ for maize, $14.0 \%$ for wheat and 18.2 for soybean according to regional data (Guerschman, 2005). This is our best estimate that 
uses average values from several studies carried-out in Argentina (5 experiments for maize, 16 for wheat and 7 for soybean), although the estimated values are in the reported range from other regions of the world (e.g. Bolinder et al., 2007). However, it does not take into account the potential variation among genotypes within each crop and the effect of other agronomical practices on the belowground to aboveground biomass ratios (Bolinder et al., 2007).

Total biomass inputs to the soil were calculated as the sum of aboveground and belowground biomass. Total crop yields and biomass inputs of the different cropping sequences were expressed as cumulative values in the two-year period. We considered that aboveground biomass, belowground biomass and total biomass represented the crop residue inputs added to the soil.

Grain yields were determined by harvesting the two central rows in each plot for maize, three for soybean and six for wheat, using a small-plot combine. Grain yield was reported at $0 \mathrm{~g} \mathrm{~kg}^{-1}$ moisture. To account for the different composition of the grains of each crop sequence, grain yields were also expressed as glucose yield and protein yield based on literature values. We considered that the required single glucose units to produce a single grain unit are 1.25 for maize, 1.39 for wheat and 1.82 for soybean (Vertregt and Penning de Vries, 1987; Andrade, 1995; Caviglia et al., 2013). Additionally, grain yield was expressed as protein yield, using local data of grain-N concentration $\left(11 \mathrm{~g} \mathrm{~N} \mathrm{~kg}^{-1}\right.$ for maize, $24 \mathrm{~g} \mathrm{~N} \mathrm{~kg}^{-1}$ for wheat, and $62 \mathrm{~g} \mathrm{~N} \mathrm{~kg}^{-1}$ for soybean) and considering that $\mathrm{N}$ content in grain protein represented $160 \mathrm{~g} \mathrm{~N} \mathrm{~kg}^{-1}$ for maize, $172 \mathrm{~g} \mathrm{~N} \mathrm{~kg}^{-1}$ for wheat and $175, \mathrm{~g} \mathrm{~N} \mathrm{~kg}^{-1}$ for soybean, according to Jones (1941) and Merril and Watt (1973). 


\subsection{Soil Sampling and laboratory analyses}

In June 2010, two years after the beginning of the experiment, two replicates of undisturbed soil samples were carefully collected in each plot from the 0-5 and 5-15 cm depths using a shovel (approximately $1 \mathrm{~kg}$ each replicate) for the determination of water-stable aggregates. To ensure that the soil sample was uniform from top to bottom, we sampled each depth separately, removing all surface layer before take the deeper sample. In addition, ten soil subsamples at 0-5, 5-15 and 15-30 $\mathrm{cm}$ depths were collected with a $2 \mathrm{~cm}$-wide soil core sampler for determining SOC concentration. After sampling, each replicate for determining water-stable aggregates were composited, passed through $1 \mathrm{~cm}$ mesh-sieve, roots removed, air-dried and stored at room temperature until analysis. Soil samples for SOC concentration were composited, airdried, ground, sieved through $2 \mathrm{~mm}$ mesh and analyzed by dry combustion using a LECO autoanalyzer model TRU SPEC (Leco Corp., St. Joseph, MI, USA).

Bulk density at 0-5, 5-15 and 15-30 cm depths were determined at the beginning of the experiment and after two years, using soil cores (height $3.0 \mathrm{~cm}$, diameter $5.4 \mathrm{~cm}$, volume $68.7 \mathrm{~cm}^{3}$ ) (Forsythe, 1975). The cumulative mass approach was used to estimate SOC stocks changes based on measured bulk density and SOC concentration for each soil depth interval (0-5, 5-15 and 15-30 cm depths) (Gifford and Roderick, 2003, Wingeyer et al., 2012). For each soil, three reference soil masses were considered to evaluate changes in SOC stocks over time on an equivalent soil mass basis: i) the top $550 \mathrm{Mg}$ soil ha ${ }^{-1}$ for the Vertisol and $600 \mathrm{Mg}$ soil ha $^{-1}$ for the Mollisol (approximately 0-5 cm depth), ii) the top $1750 \mathrm{Mg}$ soil ha ${ }^{-1}$ for the Vertisol and $2000 \mathrm{Mg}$ soil ha ${ }^{-1}$ for the Mollisol (approximately $0-15 \mathrm{~cm}$ depth), and iii) the top $3500 \mathrm{soil} \mathrm{ha}^{-1}$ for the Vertisol and $4000 \mathrm{Mg}$ soil ha ${ }^{-1}$ for the (approximately 0-30 $\mathrm{cm}$ depth) (Davidson and Ackerman, 1993). 
Water-stable aggregates were separated using the wet-sieve method described by Wright and Hons (2004) with modifications. Briefly, $100 \mathrm{~g}$ soil samples were saturated by capillary with tap water for 10 min to minimize slaking following immersion. The saturated soil was then immersed in water on a nest of sieves $(2000 \mu \mathrm{m}, 250 \mu \mathrm{m}$ and 53 $\mu \mathrm{m})$ and shaken vertically $6 \mathrm{~cm} 60$ times for 2 -min. This time was selected to ensure a minimum amount of largest macroaggregates according to preliminary tests (Novelli et al., 2011). The soil aggregates retained on the sieves were backwashed with distilled water, transferred to containers, oven-dried at $60{ }^{\circ} \mathrm{C}$ for $3 \mathrm{~d}$ and weighed. For this work, the largest macroaggregates $(>2000 \mu \mathrm{m})$ and the small macroaggregates $(250-2000 \mu \mathrm{m})$ were pooled in order to obtain a composite sample. The proportion of total aggregates presented as macroaggregates $(>250 \mu \mathrm{m})(\mathrm{MA})$, was used to compare between cropping sequences. The SOC stored inside macroaggregates $\left(\mathrm{SOC}_{\mathrm{MA}}\right)$ were expressed as equivalent soil mass. An aliquot of the composited sample of MA, was ground and sieved through $0.5 \mathrm{~mm}$ mesh and, analyzed to determine $\mathrm{C}$ concentration by dry combustion. In the Vertisol, the weight of aggregates and SOC concentration was corrected by inorganic-C content since calcium carbonate was detected. In fact, the visible calcium carbonates concretions of each total soil and MA samples were removed by sieving and the remaining calcium carbonate was determined by the pressurecalcimeter method described by Loeppert and Suarez (1996).

\subsection{Statistical analyses}

We used a mixed model to compare the different cropping sequences and soils and their interaction. The statistical model included the cropping sequences and soil type as fixed effects and replicates as a random effect. When significant differences were detected by the ANOVA, means were compared using an LSD test $(\alpha=0.05)$. 
Relationships between cropping intensity, residue input and SOC storage were evaluated through regression analyses, using the means of each treatment. We fit a linear regression for each soil type, between CI and the response variables, i.e. SOC stock, MA, $\mathrm{SOC}_{\mathrm{MA}}$, and biomass. All before statistical analyses were performed using INFOSTAT software (Di Rienzo et al., 2011).

\section{Results}

Soil organic C stocks, macroaggregates (MA) and SOC stored inside macroaggregates $\left(\mathrm{SOC}_{\mathrm{MA}}\right)$ increased from simple rotations (soybean monoculture) to more complex rotations (double cropping with cereals and legumes) only in the Mollisol and at the surface soil layer (Table 2). SOC contents and MA were higher in the Mollisol than in the Vertisol at all depths $(P<0.001)$. In both soils, W/S-W/S and $\mathrm{CC} / \mathrm{S}-\mathrm{CC} / \mathrm{S}$ rotations had the highest SOC stocks, percentage of MA and $\mathrm{SOC}_{\mathrm{MA}}$ in the surface soil layer and soybean monoculture had the lowest. At $5-15 \mathrm{~cm}$ depth, SOC stocks were higher in S-S, S-M and W/S-M than in CC/S-CC/S (Table 2).

Soil organic $\mathrm{C}$ stocks and $\mathrm{SOC}_{\mathrm{MA}}$ were positively related with $\mathrm{CI}$ in both soils at 0-5 cm depth $(P<0.1)$ for the Mollisol and $(\mathrm{P}<0.01)$ for the Vertisol (Fig. 2). Regression models showed that SOC stocks were higher in the Mollisol than in the Vertisol, at an equivalent value of CI, without differences in slope (Fig. 2a). However, at low values of $\mathrm{CI}, \mathrm{SOC}_{\mathrm{MA}}$ values were similar between soils, but differences between soils became higher with increases in CI (Fig. 2c), as a result of higher slope in the Mollisol than in the Vertisol. In fact, increases of $\mathrm{SOC}_{\mathrm{MA}}$ per each $10 \%$ of increase in $\mathrm{CI}$ were $0.75 \mathrm{Mg}$ $\mathrm{ha}^{-1}$ in the Mollisol and $0.43 \mathrm{Mg} \mathrm{ha}^{-1}$ in the Vertisol (Fig. 2c).

Crop residue inputs (aboveground biomass, belowground biomass and total biomass) differed among cropping sequences $(P<0.001)$ and were all significantly 
related to CI in both soils (Fig. 3). Total, aboveground and belowground biomass were, on average, higher in the Mollisol than in the Vertisol, and higher in double cropping complex sequences than in S-S soybean monoculture (Table 3). Overall, residue inputs in the S-S sequence were $35 \%$ to $43 \%$ for aboveground biomass, $44 \%$ to 50 for belowground biomass and $37 \%$ to $45 \%$ for total biomass inputs compared with biomass inputs measured in the highly intensified sequence W/S-W/S, for the Mollisol and Vertisol, respectively. Overall, at low CI values the amount of crop residues were similar between soil types, but at higher CI values crop residues were higher in the

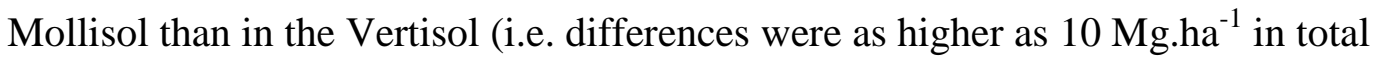
biomass at high cropping intensity levels, $\mathrm{CI}>0.66$ ) (Figure 3c).

Total grain, glucose, and protein yields were affected by soil $(P<0.001)$, cropping sequence $(P<0.001)$ and the interaction soil*cropping sequence $(P<0.01)$. The highest yields of grain, glucose and protein occurred in the Mollisol and the sequence W/S-M had the highest yields in both soils with the exception of protein yield that was higher in the sequence W/S-W/S (Fig. 4). Soybean monoculture (S-S) or soybean with cover crops $(\mathrm{CC} / \mathrm{S}-\mathrm{CC} / \mathrm{S})$ had the lowest yields, but had better performance in term of their protein yields (Fig. 4c).

\section{Discussion}

Our work provides evidence of a positive association between CI and SOC storage, and particularly in MA ( $\left.\mathrm{SOC}_{\mathrm{MA}}\right)$, in two different soils, reinforcing the role of $\mathrm{CI}$ as a valuable strategy to improve SOC sequestration, even in humid temperate environments where soils are hypothetically closer to its $\mathrm{C}$ saturation thresholds than in semiarid agroecosystems (Hassink and Whitmore, 1997, Six et al., 2002). Nonetheless, 
it should be mentioned that the $\mathrm{C}$ saturation deficit for the $\mathrm{S}-\mathrm{S}$ soybean monoculture in our experiments was ca. $50 \%$.

Our results showed significant changes in SOC stocks associated with cropping intensity in relatively short periods (only two years), indicating that detectable effects of increasing CI on SOC may be recorded early in humid temperate agroecosystems. Total SOC stocks in semiarid regions are usually less variable in the short-term, requiring several years to detect significant changes (Wood et al., 1991; Bowman, 1999). Our faster changes can be attributable to: i) the higher carbon inputs to the soil from crop residues in our more productive agroecosystems than the reported for semiarid regions (e.g. Farahani et al., 1998; Bowman et al., 1999; Sherrod et al., 2003, Shaver et al., 2003; Blanco-Canqui et al., 2010; Mikha et al., 2010), and ii) the longer growing season in humid temperate vs semiarid agroecosystems, which favors the soil protection for erosive factors and the action of stabilization agents of SOC derived from a more continuous activity of roots and microorganisms along the year (Caviglia and Andrade, 2010). Differences in temperature and soil texture may also be involved in the early changes documented in our work, as compared with the reported in semiarid regions (Hassink and Whitmore, 1997).

In agreement with other studies, $\mathrm{SOC}_{\mathrm{MA}}$ showed stronger increases than total SOC stocks with increasing cropping intensity (Six et al., 1999, 2000). The greater increase in $\mathrm{SOC}_{\mathrm{MA}}$ in the Mollisol compared with the Vertisol may be related to a higher soil aggregation response in the Mollisol occurred with increasing CI. Soil aggregation is crucial for SOC preservation and storage by imposing a physical barrier between microbial decomposers and SOC, which can be altered rapidly by management practices (Beare et al., 1994) and cropping intensity, as was showed here. This result is in agreement with a previous study (Novelli et al., 2013), which indicates a close 
relationship between SOC concentration and aggregate stability in the Mollisol but not in the Vertisol. The predominant control of inorganic agents, i.e. clay mineralogy, on soil aggregation processes in the Vertisol (Fabrizzi et al., 2009; Novelli et al., 2013) could be responsible of the lower effect of cropping sequences on soil MA, than the Mollisol.

Our results indicated that crop residue input and $\mathrm{SOC}_{\mathrm{MA}}$ in both soil types, by the increase in $\mathrm{CI}$, were reached maintaining $(\mathrm{CC} / \mathrm{S}-\mathrm{CC} / \mathrm{S})$ or increasing $(\mathrm{S}-\mathrm{M}$; CC/S$\mathrm{M}, \mathrm{W} / \mathrm{S}-\mathrm{M}, \mathrm{W} / \mathrm{S}-\mathrm{W} / \mathrm{S}$ ) grain productivity in comparison with the predominant crop sequence (S-S) in the region (Fig. 4), which in turn was probably associated with a higher resource productivity. In fact, the water productivity of crop sequences, i.e. the amount of grain per unit annual rainfall (Caviglia et al., 2004), was highest in the sequence W/S-M in both soils $\left(8.3 \mathrm{~kg} \mathrm{ha}^{-1} \mathrm{~mm}^{-1}\right.$ in the Mollisol vs $5.3 \mathrm{~kg} \mathrm{ha}^{-1} \mathrm{~mm}^{-1}$ in the Vertisol) and lowest in the soybean monoculture (S-S) $\left(2.2 \mathrm{~kg} \mathrm{ha}^{-1} \mathrm{~mm}^{-1}\right.$ in the Mollisol vs $1.4 \mathrm{~kg} \mathrm{ha}^{-1} \mathrm{~mm}^{-1}$ in the Vertisol), which are in agreement with previous reports in our region (Caviglia et al., 2004, 2013). Accordingly, our results support the concept that CI improves soil quality and productivity, probably more related with improvements in the capture of environmental resources (water, radiation) and nutrients than to improvements in resource use efficiency.

The increase of CI appears under no-till, in consequence, as a powerful tool to avoid the progressive soil degradation in the soils of northeastern Argentinean Pampas by providing a higher residue input, increasing soil protection and SOC storage, in comparison with the predominant sequence based on soybean as a single crop in the year. Also, the improvement in grain production per unit area and year associated with a high CI, is a valuable option to satisfy the increasing demand for food, fiber and biofuels, reducing the pressure on more fragile and less productive environments 
(Caviglia and Andrade, 2010). Our evidence provides information for stakeholders and policy-makers useful to develop agricultural practices oriented to improve SOC sequestration and soil health. This should be helpful to deal with the growing concerns about the negative impacts of current simplified (soybean monoculture) agroecosystems in South America.

\section{Conclusions}

The increase in CI improved crop residue input in both soil types, with a higher productivity in the Mollisol. All soil variables were lowest in simple rotations (soybean monoculture) and increased with more complex rotations (double cropping with cereals and legumes), although differences were significant only in the top soil (0-5 cm depth) The improvements in crop residue input and $\mathrm{SOC}_{\mathrm{MA}}$ in both soil types, by the increase in $\mathrm{CI}$, were reached maintaining $(\mathrm{CC} / \mathrm{S}-\mathrm{CC} / \mathrm{S})$ or increasing $(\mathrm{S}-\mathrm{M}$; CC/S-M, W/S-M, $\mathrm{W} / \mathrm{S}-\mathrm{W} / \mathrm{S}$ ) grain productivity in comparison with the predominant crop sequence (S-S) in the region. The increase in $\mathrm{SOC}_{\mathrm{MA}}$ was greater in the Mollisol than in the Vertisol, due to a higher soil aggregation response.

\section{Acknowledgments}

Thanks the staff of Natural Resources Group INTA Parana for their valuable contribution in the conduction of the experiments. This work was supported by INTA, PNSUELO 1134042, ANPCyT-UNER-CAFESG-INTA (PICT 2009 - 0220). We also thank $\mathrm{PhD}$. Ana Wingeyer and the anonymous reviewers for helping us with useful suggestions to improve the manuscript. L.E. Novelli holds a scholarship of CONICET, and O.P. Caviglia and G. Piñeiro are members of CONICET, the National Research Council of Argentina. G.P. was also supported by PIP 555 and grant from the Inter- 
American Institute for Global Change Research (IAI) CRN3095 which is supported by the US National Science Foundation (Grant GEO-1128040).

\section{References}

Acosta-Martínez, V., Mikha, M.M., Vigil, M.F, 2007. Microbial communities and enzyme activities in soils under alternative crop rotations compared to wheatfallow for the Central Great Plains. Appl. Soil Ecol. 37, 41-52.

Allen, R.G., Pereira, L.S., Raes, D., Smith, M, 2006. Evapotranspiración del cultivo. Guías para la determinación de los requerimientos de agua de los cultivos. Estudio para Riego y Drenaje 56, FAO, Roma.

Alvarez, C.R., Taboada, M.A., Gutierrez Boem, F.H., Bono, A., Fernandez, P.L., Prystupa, P., 2009. Topsoil properties as affected by tillage systems in the Rolling Pampa of Argentina. Soil Sci. Soc. Am. J. 73, 1242-1250.

Álvaro-Fuentes, J., Cantero-Martínez, C., López, M.V., Paustian, K., Denef, K., Stewart, C.E., Arrúe, J.L., 2009. Soil aggregation and soil organic carbon stabilization: effects of management in semiarid mediterranean agroecosystems. Soil Sci. Soc. Am. J. 73, 1519-1529.

Álvaro-Fuentes, J., Arrúe, J.L., Gracia, R., López, M.V., 2008. Tillage and cropping intensification effects on soil aggregation: Temporal dynamics and controlling factors under semiarid conditions. Geoderma 145, 390-396.

Andrade, F.H., 1995. Analysis of growth and yield maize, sunflower and soybean grown at Balcarce, Argentina. Field Crop Res. 41, 1-12.

Beare, M.H., Cabrera, M.L., Hendrix, P.F., Coleman, D.C., 1994. Aggregate-Protected and Unprotected Organic Matter Pools in Conventional- and No-Tillage Soils. Soil Sci. Soc. Am. J. 58, 787-795. 
Blanco-Canqui, H., Stone, L.R., Stahlman, P.W., 2010. Soil response to long-term cropping systems on an Argiustoll in the Central Great Plains. Soil Sci. Soc. Am. J. 74, 602-611.

Bolinder, M.A., Janzen, H.H., Gregorich, E.G., Angers, D.A., VandenBygaart, A.J., 2007. An approach for estimating net primary productivity and annual carbon inputs to soil for common agricultural crops in Canada. Agr. Ecosyst. Environ. $118,29-42$.

Boserup, E., 1965. The conditions of Agricultural Growth, Aldine Press, Chicago, IL, 124 pp.

Bowman, R.A., Vigil, M.F., Nielsen, D.C., Anderson, R.L., 1999. Soil organic matter changes in intensively cropped dryland systems. Soil Sci. Soc. Am. J. 63, 186191.

Calviño, P.A., Monzón, J.P., 2009. Farming systems of Argentina: yield constraints and risk management. In: Sadras, V.O. and D.F. Calderini (Eds.), Crop Physiology: Applications for Genetic Improvement and Agronomy. Academic Press, San Diego, pp. 55-70.

CASAFE, 2005. Guía de productos fitosanitarios para la República Argentina. 12va. Edición. Cámara de Sanidad Agropecuaria y Fertilizantes. 2079 p.

Caviglia, O.P., Andrade, F.H., 2010. Sustainable intensification of agriculture in the Argentinean Pampas: capture and use efficiency of environmental resources. Am. J. Plant Sci. Biotechnol. 3, 1-8.

Caviglia, O.P., Sadras, V.O., Andrade, F.H., 2004. Intensification of agriculture in the south-eastern Pampas. I. Capture and efficiency in the use of water and radiation in double-cropped wheat-soybean. Field Crops Res. 87, 117-129. 
Caviglia, O.P., Sadras, V.O., Andrade, F.H., 2011. Yield and quality of wheat and soybean in sole- and double-cropping. Agron. J. 103, 1081-1089.

Caviglia, O.P., Sadras, V.O., Andrade, F.H., 2013. Modelling long-term effects of cropping intensification reveals increased water and radiation productivity in the South-eastern Pampas. Field Crop Res. 149, 300-311.

Chung, H., Ngo, K.J., Plante, A., Six, J., 2009. Evidence for carbon saturation in a highly structured and organic-matter-rich soil. Soil Sci. Soc. Am. J. 74, 130-138.

Davidson, E., Ackerman, I. 1993. Changes in soil carbon inventories following previously untilled soils. Biogeochemistry, 20(3), 161-193. Retrieved from http://link.springer.com/article/10.1007/BF00000786

Di Rienzo, J.A., Casanoves, F., Balzarini, M.G., Gonzalez, L., Tablada, M., Robledo, C.W., 2011. InfoStat versión 2011. Grupo InfoStat, FCA, Universidad Nacional de Córdoba, Argentina. URL http://www.infostat.com.ar

Doré, T., Makowski, D., Malézieux, E., Munier-Jolain, N., Tchamitchian, M., Tittonell, P., 2011. Facing up to the paradigm of ecological intensification in agronomy: revisiting methods, concepts and knowledge. Europ. J. Agronomy 34, 197-210.

Fabrizzi, K.P., Rice, C.W., Amado, T.J.C., Fiorin, J., Barbagelata, P., Melchiori, R., 2009. Protection of soil organic $\mathrm{C}$ and $\mathrm{N}$ in temperate and tropical soils: effect of native and agroecosystems. Biogeochemistry. 92, 129-143.

Farahani, H.J., Peterson, G.A., Westfall, D.G., 1998. Dryland cropping intensification: a fundamental solution to efficient use of precipitation. Adv. Agron. 64, 197-223.

Fehr, W.R., Caviness, C.E., 1977. Stages of soybean development. Special Report 80. Iowa State University, Ames, Iowa. 11 p.

Forsythe, W., 1975. Física de suelos. IICA, San José, Costa Rica. 212 pp 
Franzluebbers, A.J., Hons, F.M., Zuberer, D.A., 1994. Long-term changes in soil carbon and nitrogen pools in wheat management systems. Soil Sci. Soc. Am. J. 58, $1639-1645$.

Gifford, R.M., Roderick M.L., 2003. Soil carbon stocks and bulk density: spatial or cumulative mass coordinates as a basis of expression? Global Change Biology 9 , $1507-1514$.

Guerschman J.P., 2005. Análisis regional del impacto de los cambios del uso de la tierra sobre el funcionamiento de los ecosistemas en la Región Pampeana (Argentina). Tesis (Doctor en Cs. Agropecuarias) Buenos Aires, Argentina. Universidad de Buenos Aires, Facultad de Agronomía: 143p

Hassink, J., Whitmore, A.P., 1997. A model of the physical protection of organic matter in soils. Soil Sci. Soc. Am. J. 61,131-139.

Herman, J.C., 1985. How a Soybean Plant Develops. Special Report N 53. Iowa State University of Science and Technology. Cooperative Extension Services, Ames, Iowa.

Jones, D.B., 1941. Factors for converting percentages of nitrogen in foods and feeds into percentages of protein. U.S. Dept. Agr. Cir. 183, 22pp.

Kasper, M., Buchan, G.D., Mentler, A., Blum, W.E.H., 2009. Influence of soil tillage systems on aggregate stability and the distribution of $\mathrm{C}$ and $\mathrm{N}$ in different aggregate fractions. Soil Till. Res. 105, 192-199.

Loeppert, R.H., Suarez, D.L., 1996. Carbonate and gypsum. In: Sparks, D.L. (ed.) Methods of soil analysis. Part 3, 3rd ed. Madison, WI: SSSA, ASA. pp. 437474. 
Luo, Z.K., Wang, E., Sun, O.J., 2010. Soil carbon change and its responses to agricultural practices in Australian agro-ecosystems: a review and synthesis. Geoderma 155, 211-223.

Melchiori, R.J.M., Novelli, L.E., Gregorutti, V.C., Caviglia, O.P., 2014. Stover quality and soil organic carbon in long-term nitrogen-fertilized maize. Agron. J. 106, 1709-1716.

Merrill, A.L., Watt, B.K., 1973. Energy Value of Foods...Basis and Derivation. Agriculture Handbook No. 74. U.S. Government Printing Office. Washington, DC. $105 \mathrm{p}$.

Mikha, M.M., Benjamin, J.G., Vigil, M.F., Nielson, D.C., 2010. Cropping intensity impacts on soil aggregation and carbon sequestration in the Central Great Plains. Soil Sci. Soc. Am. J. 74, 1712-1719.

Monzón, J.P., Mercau, J.L., Andrade, J.F., Caviglia, O.P., Cerrudo, A.G., Cirilo, A.G., Vega, C.R.C., Andrade, F.H., Calviño, P.A., 2014. Maize-soybean intensification alternatives for the Pampas. Field Crop Res. 162, 48-59.

Nosetto, M.D., Jobbágy, E.G., Brizuela, A.B., Jackson, R.B., 2012. The hydrologic consequences of land cover change in central Argentina. Agric. Ecosyst. Environ. 154, 2-11

Novelli, L.E., Caviglia, O.P., Melchiori, R.J.M., 2011. Impact of soybean cropping frequency on soil carbon storage in Mollisols and Vertisols. Geoderma 167-168, 254-260.

Novelli, L.E., Caviglia, O.P., Wilson, M.G., Sasal, M.C., 2013. Land use intensity and cropping sequence effects on aggregate stability and C storage in a Vertisol and a Mollisol. Geoderma 195-196, 260-267. 
Paruelo, J.M., Guerschman, J.P., Piñeiro, G., Jobbágy, E.G., Verón, S.R., Baldi, G., Baeza, S., 2006. Cambios en el uso de la tierra en Argentina y Uruguay: marcos conceptuales para su análisis. Agrociencia 10, 47-61.

Peterson, G.A., Halvorson, A.D., Havlin, J.L., Jones, O.R., Lyn, D.J., Tanaka, D.L., 1998. Reduced tillage and increasing cropping intensity in the Great Plains conserves soil C. Soil Till. Res. 47, 207-218.

Pittelkow, C.M., Liang, X., Linquist, B.A., Van Groenigen, K.J., Lee, J., Lundy, M.E., Van Gestel, N., Six, J., Venterea, R.T., Van Kessel, C., 2015. Productivity limits and potentials of the principles of conservation agriculture. Nature 517, 365-368.

Plan Mapa de Suelos, 1998. Carta de Suelos de la República Argentina. Departamento Paraná, Provincia de Entre Ríos, Serie Relevamiento de Recursos Naturales N ${ }^{\circ}$ $17,114 \mathrm{pp}$.

Ritchie, S.W., Hanway J.J., 1982. How a corn plant develops. Iowa State University of Science and Technology. Cooperative Extension Services, Ames, Iowa. Special Report 48. $21 \mathrm{pp.}$

Shaver, T.M., Peterson, G.A., Sherrod, L.A.. 2003. Cropping intensification in dryland systems improves soil physical properties: regression relations. Geoderma 166, 149-164.

Sherrod, L.A., Peterson, G.A., Westfall, D.G., Ahuja, L.R., 2003. Cropping intensity enhances soil organic carbon and nitrogen in a no-till agroecosystem. Soil Sci. Soc. Am. J. 67, 1533-1543.

Six, J., Elliot, E.T., Paustian, K., 1999. Aggregate and soil organic matter dynamics under conventional and no-tillage systems. Soil Sci. Soc. Am. J. 63, 1350-1358. 
Six, J., Paustian, K., Elliot, E.T., Combrink. C., 2000. Soil structure and organic matter: I. Distribution of aggregate-size classes and aggregate associated carbon. Soil Soil Sci. Soc. Am. J. 64, 681-689.

Six, J., Conant, R.T., Paul, E.A., Paustian, K., 2002. Stabilization mechanisms of soil organic matter: Implication for C-saturation soils. Plant and Soil 241, 155-176.

Soil Survey Staff, 2010. Keys to Soil Taxonomy, eleventh ed. United States Departament of Agriculture. Natural Resources Conservation Service, 346 pp.

Studdert, G.A., Echeverría, H.E., 2000. Crop rotations and nitrogen fertilization to manage soil organic carbon dynamics. Soil Sci. Soc. Am. J. 64, 1496-1503.

Vertregt, N., Penning de Vries, F.W.T., 1987. A rapid method for determining the efficiency of biosynthesis of plant biomass. J. Theor. Biol. 128, 109-119.

Wingeyer, A.B., Walters, D.T., Drijber, R.A., Olk, D.C., Arkebauer, T.J., Verma, S.B., Wedin, D.A., Francis, C.A., 2012. Fall conservation deep tillage stabilizes maize residues into soil organic matter. Soil Sci. Soc. Am. J. 76, 2154-2163.

Wingeyer, A.B., Amado, T.J.C., Pérez-Bidegain, M., Studdert, G.A., Perdomo Varela, C.H., García, F.O., Karlen, D.L., 2015. Soil quality impacts of current South American agricultural practices. Sustainability 7, 2213-2242.

Wischmeier, W.H., Smith, D.D., 1978. Predicting rainfall erosion losses - a guide to conservation planning. U.S. Department of Agriculture, Agriculture Handbook $\mathrm{N}^{\circ} 537$.

Wood, C.W., Westfall, D.G., Peterson, G.A., 1991. Soil carbon and nitrogen changes on initiation of no-till cropping systems. Soil Sci. Soc. Am. J. 55, 470-476.

Wood, C.W., Westfall, D.G., Peterson, G.A., Burke, I.C., 1990. Impacts of cropping intensity on carbon and nitrogen mineralization under no-till dryland agroecosystems. Agron. J. 82, 1115-1120. 
Wright, A.L., Hons, F.H., 2004. Soil aggregation and carbon and nitrogen storage under soybean cropping sequences. Soil Sci. Soc. Am. J. 68, 507-513.

Wright, A.L., Hons, F.H., 2005. Soil carbon and nitrogen storage in aggregates from different tillage and crop regimes. Soil Sci. Soc. Am. 69, 141-147.

Zadoks, J.C., Chang, T.T., Konzak, C.F., 1974. A decimal code for the growth stage of cereals. Weed Res. 14, 415-421. 


\section{Figure Captions}

Fig. 1. Schematic diagram of the cropping sequences, over the two-year period, used in the experiments carried-out in a Mollisol and a Vertisol at Paraná, Argentina (31 $51^{\prime}$ S; $60^{\circ} 32^{\prime} \mathrm{W}$ ). Black horizontal bars represent the periods with actively growing (green) crops, whereas grey horizontal bars represent fallow periods. S-S: soybean monoculture; S-M: soybean-maize; CC/S-M: wheat cover crop/soybean-maize; W/S-M: wheat/soybean-maize; CC/S-CC/S: wheat cover crop/soybean; W/S-W/S: wheat/soybean. In the abbreviation of cropping sequences, hyphens separate years, whereas slashes separate crops within the same year. Lines on the bars indicate the standard deviation of the mean.

Fig. 2. Relationship between cropping intensity (CI) and: a) total SOC stocks; b) the percentage of macroaggregates (MA) and c) SOC stocks inside aggregates $\left(\mathrm{SOC}_{\mathrm{MA}}\right)$ at 0-5 cm depth in a Mollisol and a Vertisol at Paraná, Argentina (31 ${ }^{\circ} 51^{\prime} \mathrm{S} ; 60^{\circ} 32^{\prime} \mathrm{W}$ ). Bars indicate the standard deviation of the mean.

Fig. 3. Relationship between residue inputs a) aboveground biomass (AB); b) belowground biomass $(\mathrm{BB})$; c) total biomass $(\mathrm{TB})$ and cropping intensity $(\mathrm{CI})$ for different cropping sequences in a Mollisol and a Vertisol at Paraná, Argentina (31 ${ }^{\circ} 51^{\text {’ }}$ $\left.\mathrm{S} ; 60^{\circ} 32^{\prime} \mathrm{W}\right)$. Bars indicate the standard deviation of the mean.

Fig. 4. Cumulative grain yields (a), glucose equivalent yields (b) and protein yields (c), in different crop sequences in a Mollisol and a Vertisol at Paraná, Argentina (31 $51^{\prime}$ S; $\left.60^{\circ} 32^{\prime} \mathrm{W}\right)$. Different letters on the bars indicate significant differences between cropping sequences within a soil type according to LSD test $(\alpha=0.05)$. Uppercase 
indicate differences in the Mollisol, whereas lowercase indicate differences in the Vertisol. S-S: soybean monoculture; S-M: soybean-maize; CC/S-M: wheat cover crop/soybean-maize; W/S-M: wheat/soybean-maize; CC/S-CC/S: wheat cover crop/soybean; W/S-W/S: wheat/soybean. In the abbreviation of cropping sequences, hyphens separate years, whereas slashes separate crops within the same year. Lines on the bars indicate the standard deviation of the mean. 
Table 1. Monthly rainfall (R), mean air temperature $(\mathrm{T})$ and potential evapotranspiration (PET) recorded at Paraná, Argentina (3151’ S; 60³2’ W) from 2008 to 2010.

\begin{tabular}{|c|c|c|c|c|c|c|c|c|c|}
\hline & \multicolumn{3}{|c|}{2008} & \multicolumn{3}{|c|}{2009} & \multicolumn{3}{|c|}{2010} \\
\hline & $\mathrm{R}$ & $\mathrm{T}$ & PET & $\mathrm{R}$ & $\mathrm{T}$ & PET & $\mathrm{R}$ & $\mathrm{T}$ & PET \\
\hline & $\mathrm{mm}$ & ${ }^{\circ} \mathrm{C}$ & $\mathrm{mm}$ & $\mathrm{mm}$ & ${ }^{\circ} \mathrm{C}$ & $\mathrm{mm}$ & $\mathrm{mm}$ & ${ }^{\circ} \mathrm{C}$ & $\mathrm{mm}$ \\
\hline January & 97 & 25 & 173 & 35 & 25 & 178 & 222 & 25 & 160 \\
\hline February & 95 & 25 & 132 & 155 & 24 & 134 & 355 & 25 & 111 \\
\hline March & 43 & 22 & 121 & 298 & 24 & 129 & 189 & 24 & 122 \\
\hline April & 58 & 19 & 88 & 85 & 21 & 99 & 68 & 18 & 83 \\
\hline May & 73 & 17 & 60 & 34 & 18 & 73 & 79 & 15 & 53 \\
\hline June & 5 & 11 & 37 & 7 & 12 & 53 & 3 & 12 & 44 \\
\hline July & 15 & 16 & 50 & 46 & 11 & 58 & 17 & 11 & 59 \\
\hline August & 0 & 14 & 81 & 3 & 16 & 105 & 4 & 12 & 70 \\
\hline September & 33 & 16 & 108 & 101 & 14 & 84 & 72 & 15 & 90 \\
\hline October & 94 & 19 & 134 & 74 & 19 & 148 & 58 & 17 & 127 \\
\hline November & 106 & 23 & 162 & 92 & 23 & 135 & 28 & 21 & 154 \\
\hline December & 25 & 25 & 183 & 254 & 23 & 135 & 62 & 25 & 189 \\
\hline
\end{tabular}


Table 2. Total Soil organic Carbon (SOC) stocks, SOC stored inside macroaggregates $\left(\mathrm{SOC}_{\mathrm{MA}}\right)$ and the amount of macroaggregates (MA) measured two years after de beginning of the experiment (2010), at different soil depths for all cropping sequences analyzed in a Mollisol and a Vertisol at Paraná, Argentina $\left(31^{\circ} 51^{\prime} \mathrm{S} ; 60^{\circ} 32^{\prime} \mathrm{W}\right)$.

\begin{tabular}{|c|c|c|c|c|c|c|c|c|c|}
\hline \multirow{3}{*}{$\begin{array}{c}\text { Soil } \\
\text { Mollisol }\end{array}$} & \multirow{3}{*}{$\begin{array}{c}\begin{array}{c}\text { Cropping } \\
\text { sequences }\end{array} \\
\text { S-S }\end{array}$} & \multicolumn{4}{|c|}{ SOC stock $\left(\mathrm{Mg} \mathrm{ha}^{-1}\right)$} & \multicolumn{2}{|c|}{$\mathrm{SOC}_{\mathrm{MA}}\left(\mathrm{Mg} \mathrm{ha}^{-1}\right)$} & \multicolumn{2}{|c|}{ MA $(\%)$} \\
\hline & & $0-5 \mathrm{~cm}$ & $5-15 \mathrm{~cm}$ & $5-30 \mathrm{~cm}$ & $0-30 \mathrm{~cm}$ & $0-5 \mathrm{~cm}$ & $5-15 \mathrm{~cm}$ & $0-5 \mathrm{~cm}$ & $5-15 \mathrm{~cm}$ \\
\hline & & $18.6 \mathrm{bc} \dagger$ & 21.8 & 23.4 & 63.8 & $9.6 \mathrm{~d}$ & 13.1 & $59.0 \mathrm{c}$ & $54.8 b c$ \\
\hline & S-M & $18.1 \mathrm{c}$ & 24.2 & 27.1 & 69.4 & $11.7 \mathrm{bc}$ & 14.2 & 65.0abc & $62.2 \mathrm{a}$ \\
\hline & CC/S-M & $18.1 \mathrm{c}$ & 23.5 & 27.0 & 68.7 & $10.5 \mathrm{~cd}$ & 14.0 & $62.4 \mathrm{bc}$ & $55.1 \mathrm{bc}$ \\
\hline & W/S-M & $18.2 \mathrm{c}$ & 24.3 & 26.6 & 69.1 & $12.2 \mathrm{bc}$ & 15.0 & $68.1 \mathrm{ab}$ & $57.7 \mathrm{~b}$ \\
\hline & $\mathrm{CC} / \mathrm{S}-\mathrm{CC} / \mathrm{S}$ & $20.4 \mathrm{a}$ & 24.6 & 25.2 & 70.3 & $14.5 \mathrm{a}$ & 13.5 & $70.8 \mathrm{a}$ & $52.0 \mathrm{c}$ \\
\hline & W/S-W/S & $20.1 \mathrm{ab}$ & 23.6 & 24.5 & 68.2 & $13.3 \mathrm{ab}$ & 16.0 & $66.9 \mathrm{ab}$ & $55.2 \mathrm{bc}$ \\
\hline & p-value & $<0.02$ & $<0.13$ & $<0.10$ & $<0.12$ & $<0.001$ & $<0.30$ & $<0.02$ & $<0.003$ \\
\hline \multirow{8}{*}{ Vertisol } & & $0-5 \mathrm{~cm}$ & $5-15 \mathrm{~cm}$ & $5-30 \mathrm{~cm}$ & $0-30 \mathrm{~cm}$ & $0-5 \mathrm{~cm}$ & $5-15 \mathrm{~cm}$ & $0-5 \mathrm{~cm}$ & $5-15 \mathrm{~cm}$ \\
\hline & S-S & 15.4 & $25.9 \mathrm{a}$ & 31.5 & 72.7 & 9.3 & 15.5 & $57.0 \mathrm{~b}$ & 54.9 \\
\hline & S-M & 15.4 & $25.7 \mathrm{a}$ & 29.9 & 71.0 & 9.5 & 16.0 & $56.8 \mathrm{~b}$ & 56.1 \\
\hline & CC/S-M & 15.5 & $25.1 \mathrm{ab}$ & 30.9 & 71.5 & 10.6 & 15.6 & $54.1 \mathrm{~b}$ & 53.6 \\
\hline & W/S-M & 15.9 & $25.3 \mathrm{a}$ & 32.0 & 73.3 & 10.5 & 15.9 & $54.1 \mathrm{~b}$ & 53.6 \\
\hline & $\mathrm{CC} / \mathrm{S}-\mathrm{CC} / \mathrm{S}$ & 16.6 & $24.4 \mathrm{~b}$ & 31.9 & 72.9 & 11.4 & 14.5 & $59.5 b$ & 51.6 \\
\hline & W/S-W/S & 16.5 & $25.1 \mathrm{ab}$ & 33.0 & 74.5 & 11.2 & 16.4 & $65.8 \mathrm{a}$ & 56.2 \\
\hline & p-value & $<0.10$ & $<0.05$ & $<0.67$ & $<0.41$ & $<0.10$ & $<0.80$ & $<0.01$ & $<0.65$ \\
\hline
\end{tabular}

$\dagger$ Within each column, means followed by the same letter are not significantly different according to LSD (0.05). S-S: continuous soybean; S-M: soybean-maize; CC/S-M: wheat cover crop/soybean-maize; W/S-M: wheat/soybean-maize; CC/S-CC/S: wheat cover crop/soybean; W/S-W/S: wheat/soybean. In the abbreviation of cropping sequences, hyphens separate years, whereas slashes separate crops within the same year. All SOC stocks are expressed in an equivalent soil mass, see text for details. 
Table 3. Cumulative aboveground biomass, belowground biomass and total biomass of different cropping sequences from 2008 to 2010 in a Mollisol and a Vertisol at Paraná, Argentina (31⒌' S; 60³2’ W).

\begin{tabular}{|c|c|c|c|c|}
\hline Soil & Crop sequence & $\begin{array}{c}\text { Aboveground } \\
\text { biomass }\end{array}$ & $\begin{array}{c}\text { Belowground } \\
\text { biomass }\end{array}$ & $\begin{array}{c}\text { Total } \\
\text { biomass }\end{array}$ \\
\hline & & & $-\mathrm{Mg} \mathrm{ha}^{-1}$ & \\
\hline \multirow[t]{7}{*}{ Mollisol } & S-S & $11.9 \mathrm{c} \dagger$ & 4.0 & 15.9 \\
\hline & S-M & $24.3 \mathrm{~b}$ & 6.7 & 31.0 \\
\hline & CC/S-M & $30.0 \mathrm{a}$ & 7.5 & 37.6 \\
\hline & W/S-M & $32.5 \mathrm{a}$ & 9.0 & 41.5 \\
\hline & $\mathrm{CC} / \mathrm{S}-\mathrm{CC} / \mathrm{S}$ & $31.6 \mathrm{a}$ & 7.4 & 39.1 \\
\hline & W/S-W/S & $33.8 \mathrm{a}$ & 9.3 & 43.1 \\
\hline & p-value & $<0.0001$ & & \\
\hline & & & $-\mathrm{Mg} \mathrm{ha}^{-1}$ & \\
\hline \multirow[t]{7}{*}{ Vertisol } & S-S & $10.7 \mathrm{c}$ & 3.3 & 14.0 \\
\hline & S-M & $16.8 \mathrm{~b}$ & 4.7 & 21.4 \\
\hline & CC/S-M & $22.7 \mathrm{a}$ & 5.6 & 28.2 \\
\hline & W/S-M & $23.6 \mathrm{a}$ & 6.1 & 29.7 \\
\hline & $\mathrm{CC} / \mathrm{S}-\mathrm{CC} / \mathrm{S}$ & $25.1 \mathrm{a}$ & 5.6 & 30.7 \\
\hline & W/S-W/S & $24.7 \mathrm{a}$ & 6.6 & 31.3 \\
\hline & $\mathrm{p}$-value & $<0.0001$ & & \\
\hline
\end{tabular}

$\dagger$ Means followed by the same letter are not significantly different, within each soil and column, according to LSD $(\alpha=0.05)$. S-S: soybean monoculture; S-M: soybean-maize; CC/S-M: wheat cover crop/soybeanmaize; W/S-M: wheat/soybean-maize; CC/S-CC/S: wheat cover crop/soybean; W/S-W/S: wheat/soybean. Since both belowground biomass and total biomass were estimated from aboveground biomass, the statistical comparison was not included for these two variables. In the abbreviation of cropping sequences, hyphens separate years, whereas slashes separate crops within the same year. 


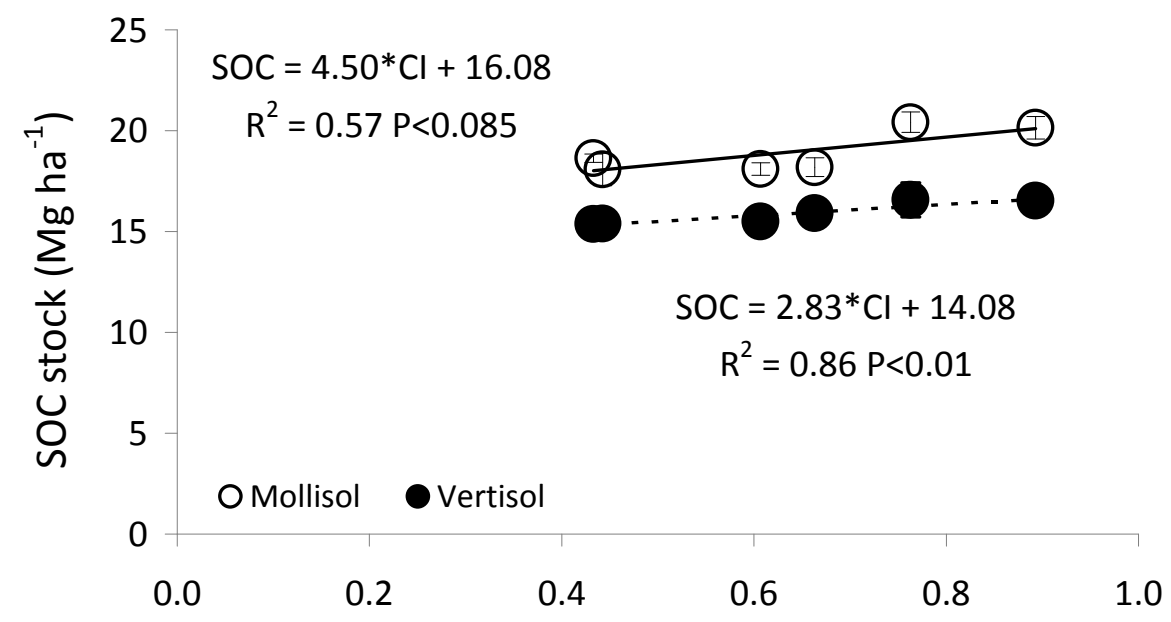

a)

Cropping Intensity index ( $\left.w k w^{-1}\right)$
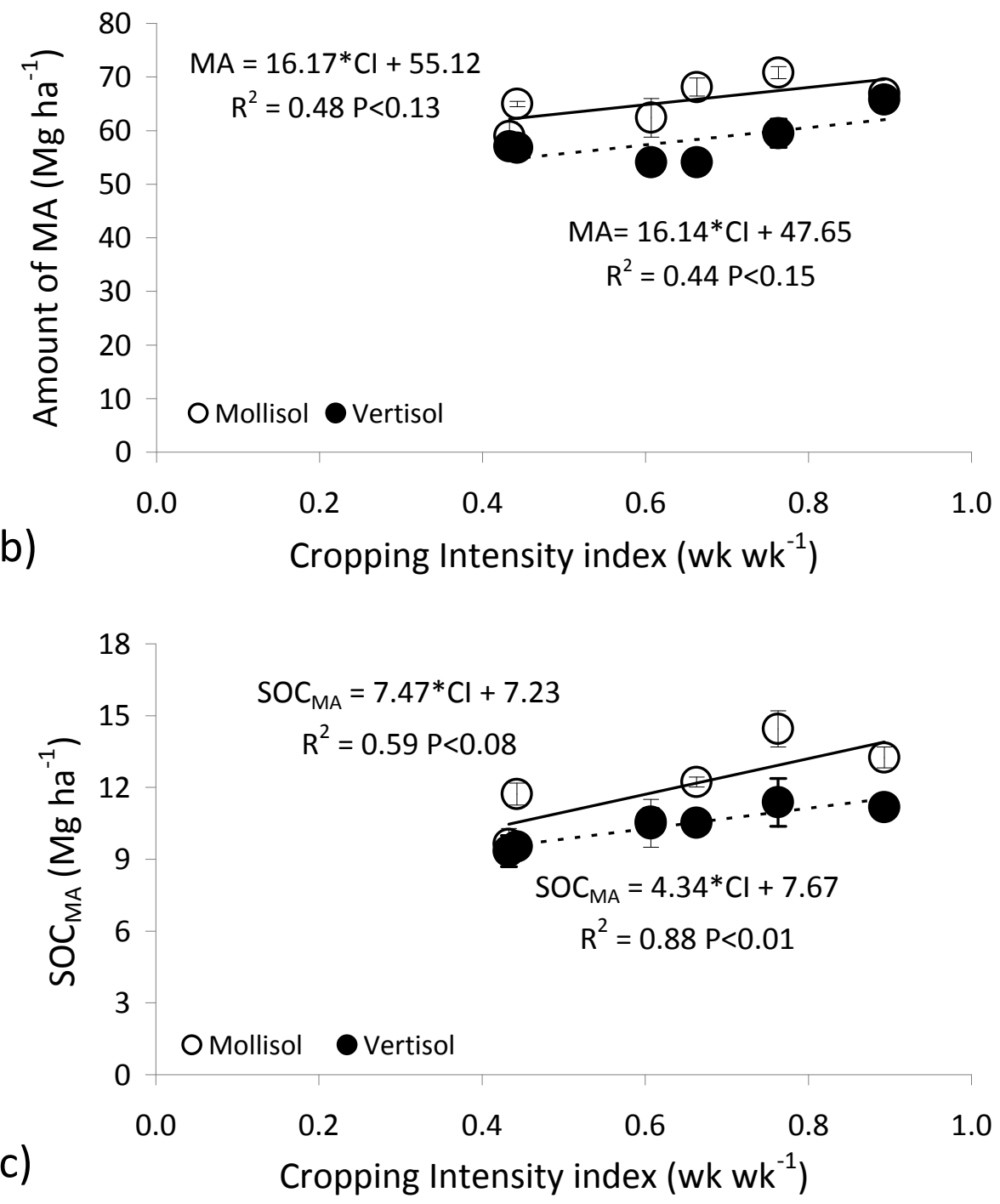


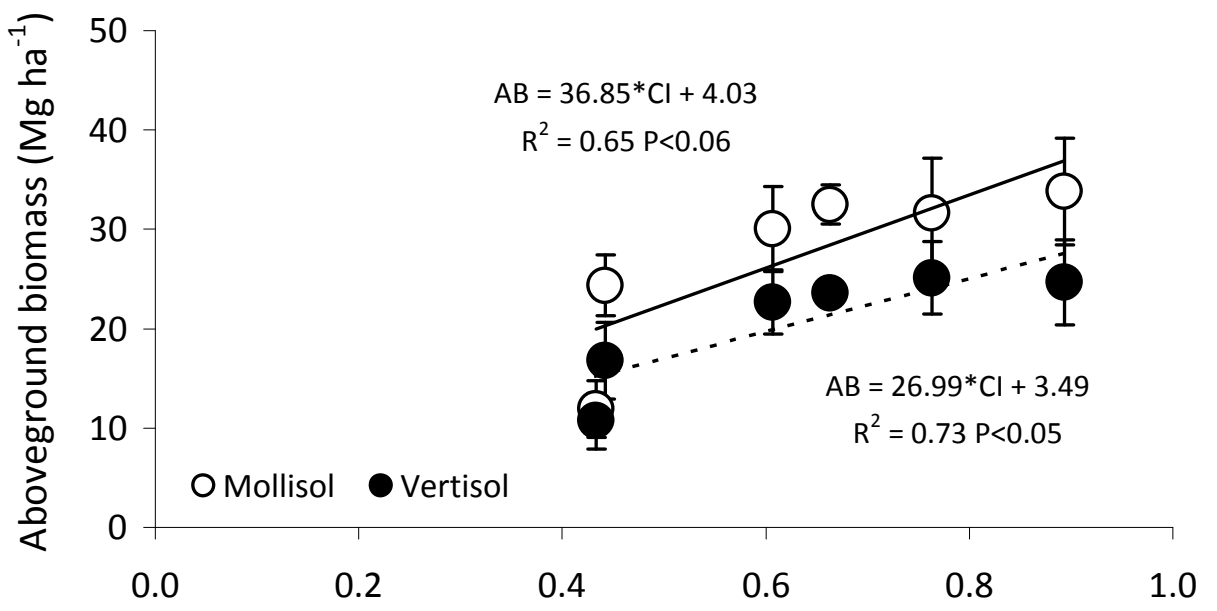

a)

Cropping Intensity Index (wk wk ${ }^{-1}$ )

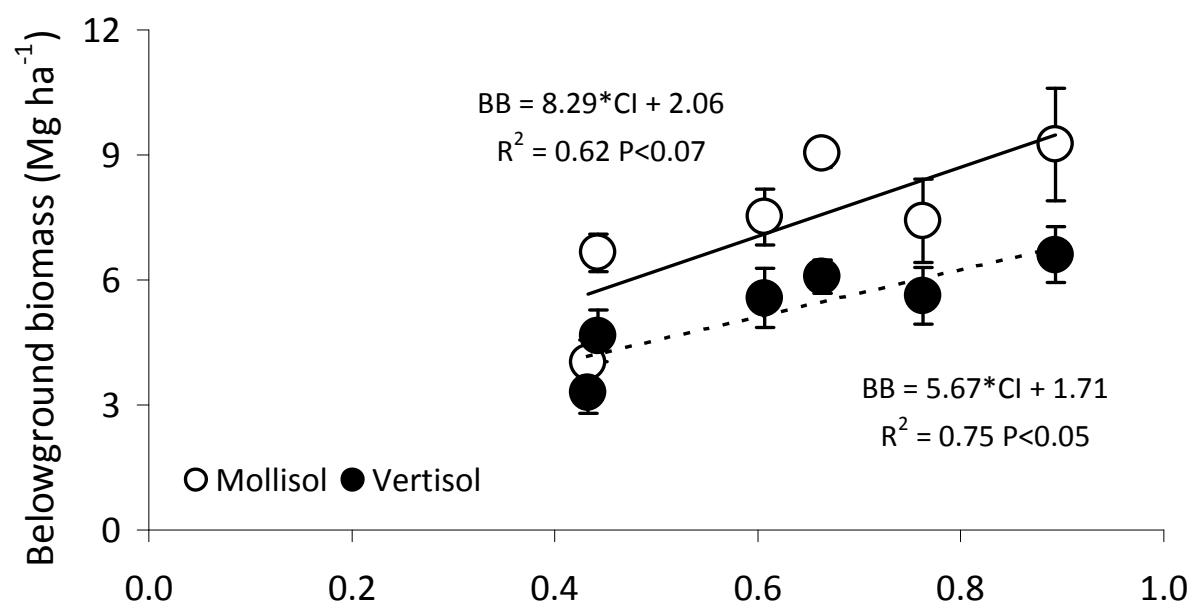

b) Cropping Intensity Index ( $w w^{-1} \mathrm{wk}^{-1}$ )

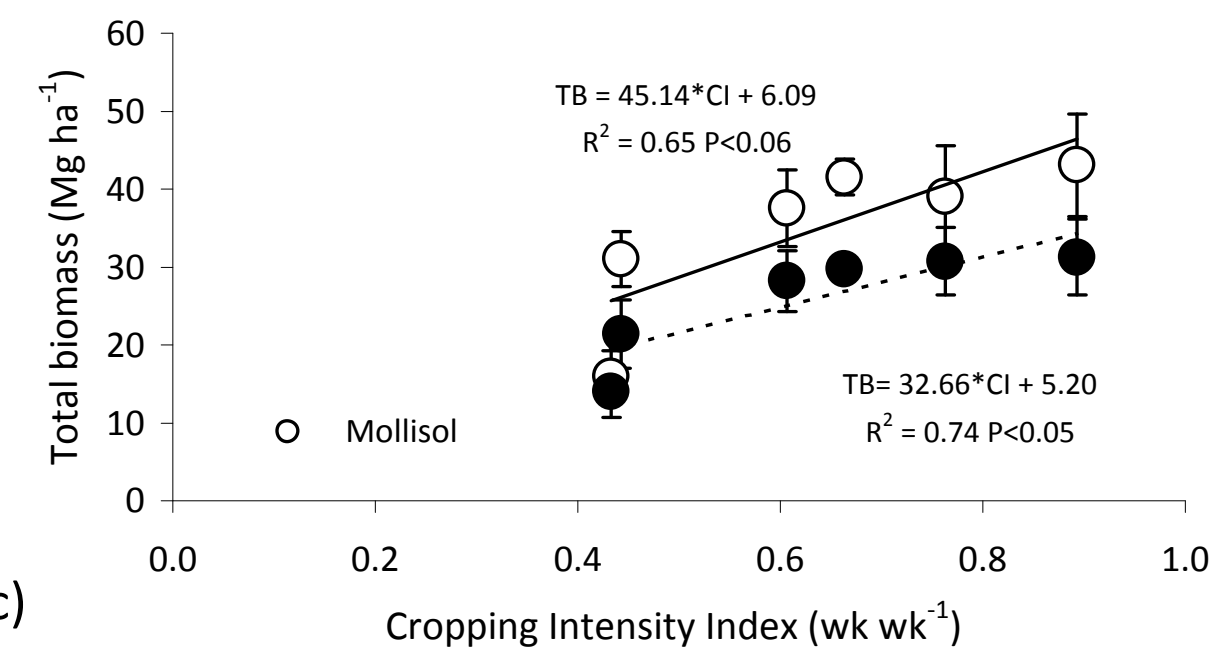


Figure 4

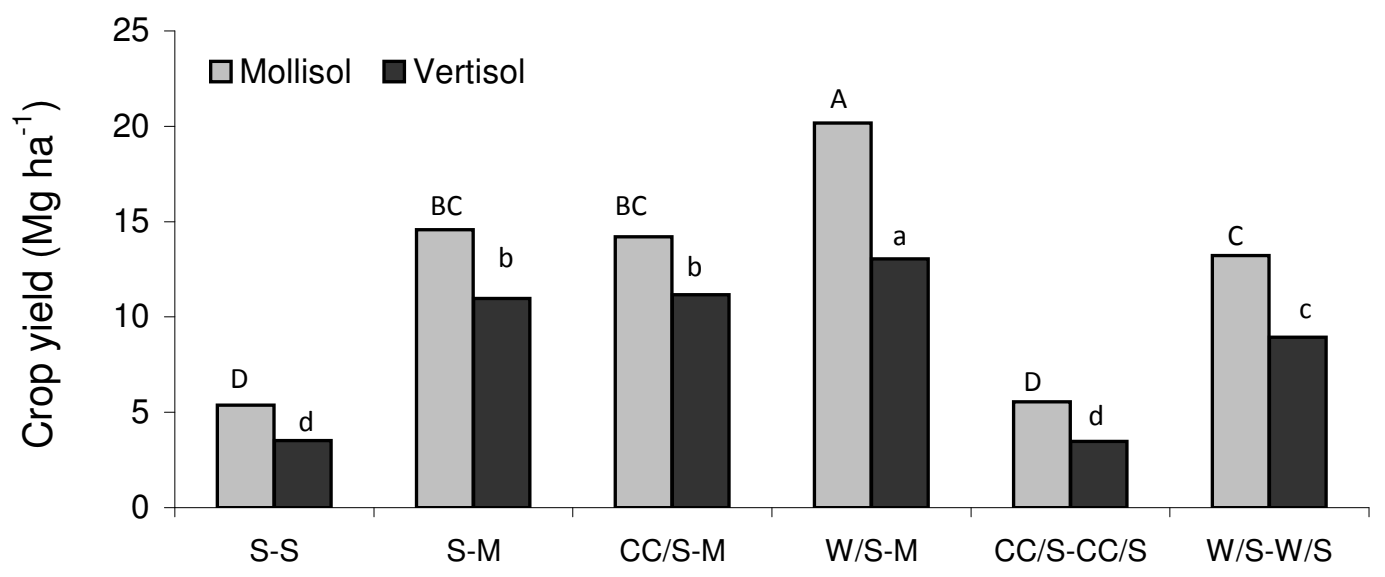

a)

Cropping sequences

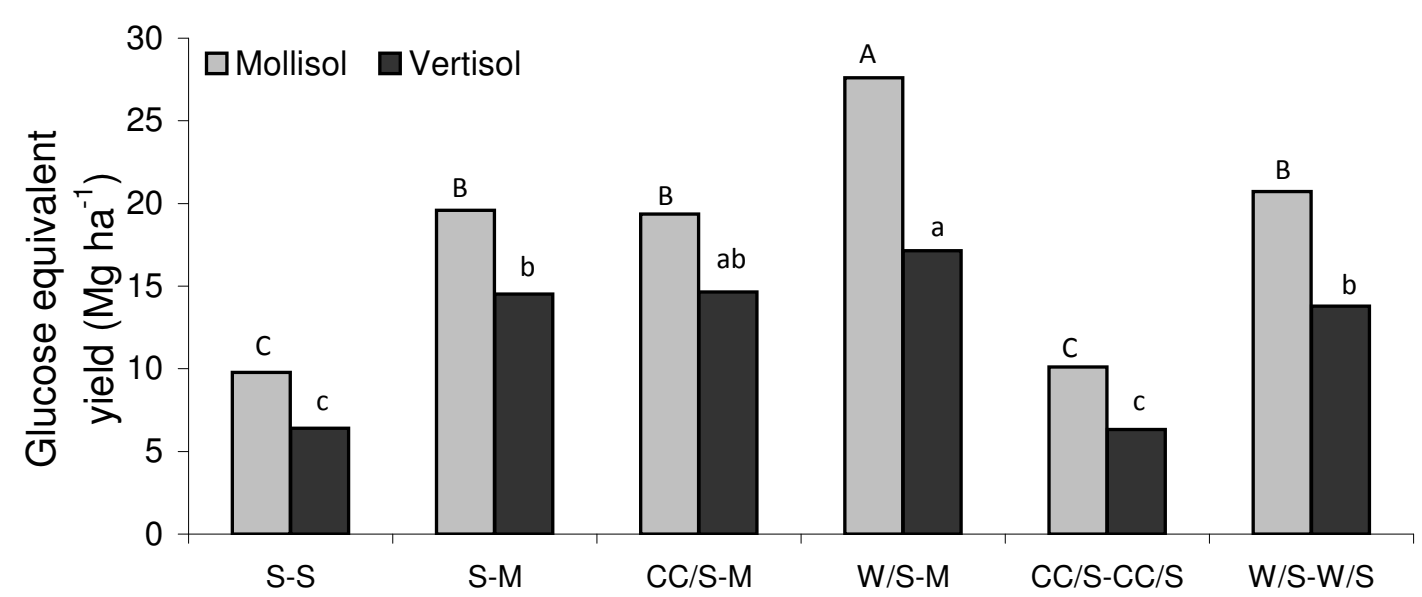

b)

Cropping sequences

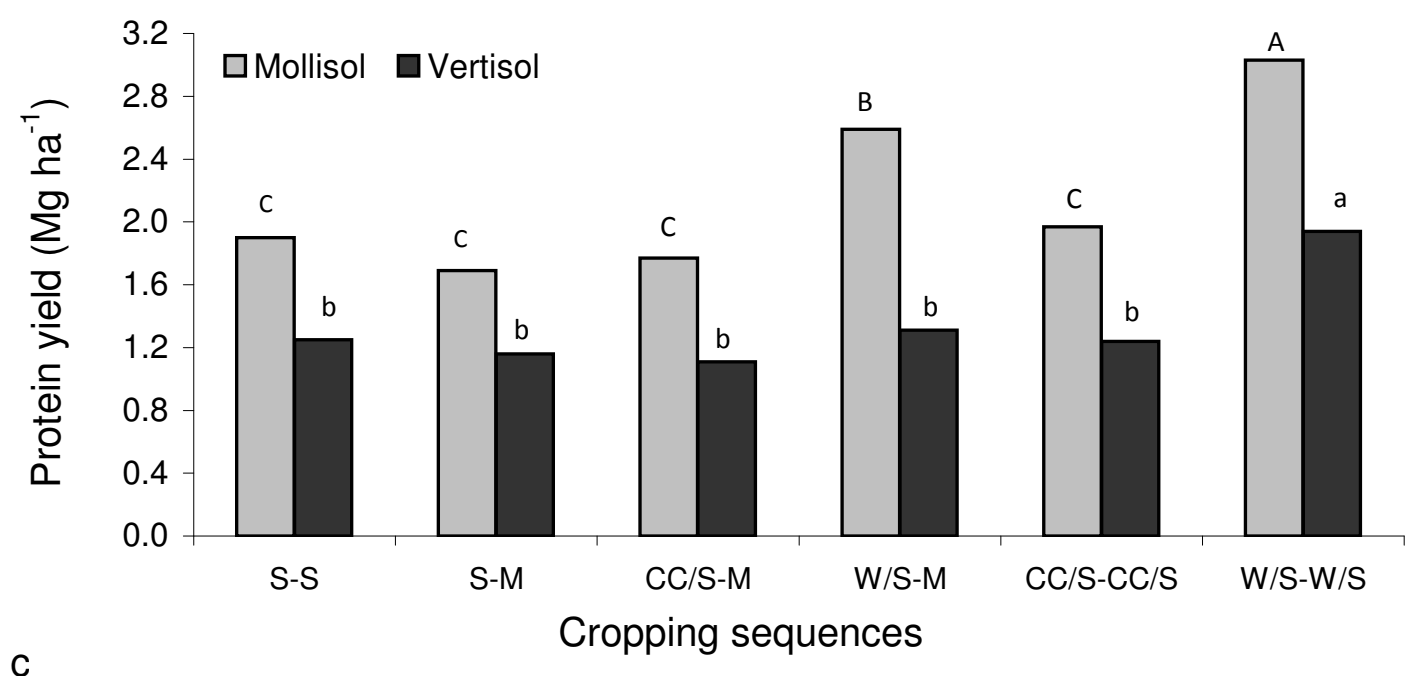

